\title{
Global Liquidity and Commodity Prices
}

\author{
Hyunju Kang* \\ Bok-Keun $\mathrm{Yu}^{* *}$ \\ Jongmin $\mathrm{Yu}^{* * *}$
}

The views expressed herein are those of the author and do not necessarily reflect the official views of the Bank of Korea. When reporting or citing this paper, the author's name should always be stated explicitly.

* Research Fellow, Korea Capital Market I nstitute, Phone: +82-2-3771-0850; Email: hjkang326@gmail.com

** Head, Senior Economist, Micro \& Institutional Economics Team, Economic Research Institute, The Bank of Korea, Phone:+82-2-759-5546; Email: bokyu@bok.or.kr

*** Assistant Professor, Hongik University, Phone: +82-2-320-1750; Email: yukono@hongik.ac.kr

We are grateful to Woon Gyu Choi, J in-Su Park, Hyun-J eong Kim, Hail Park, Ki-Ho Kim, Kyuho Kang and participants in the seminar at the Bank of Korea whose useful comments have significantly improved this paper. Miso An hel ped uswith a variety of data related tasksas our research assistant. All the remaining errors are our own. The viewsin this paper do not necessarily reflect the official views of the Bank of Korea or Korea Capital Market I nstitute. 


\section{Contents}

I. Introduction

II. Data and Empirical Methodology …….......................... 5
A. Quantity-Based Versus Price-Based Global Liquidity Measures …... 5
B. Commodity Prices, Supply, and Demand …………………………....

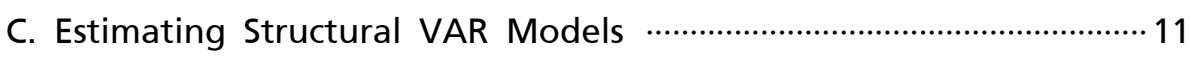

III. Impacts of Global Liquidity on Commodity Prices …15

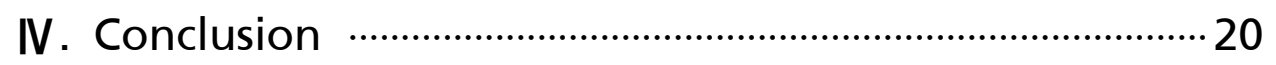

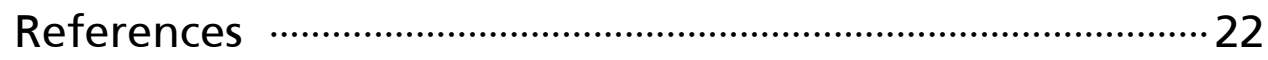




\section{Global Liquidity and Commodity Prices}

While monetary easing in major economies and the greater participation of financial institutions in commodity trading have enhanced the financialization of commodity markets since the global financial crisis, this paper empirically investigates whether the impact of global liquidity on commodity prices has grown since the crisis. For the agricultural products, energy and metals sectors, this paper uses a structural vector autoregression model of commodity supply, demand and prices with global liquidity to address the short-run relationship between global liquidity and commodity prices.

The key finding is that the effect of global liquidity has been more pronounced for energy and metals commodity prices since the global financial crisis. This paper also suggests a price-based liquidity measure has a greater explanatory power for the commodity price dynamics than commonly-used monetary aggregates in the post-crisis period.

Keywords: Commodity prices, Global liquidity, Structural vector autoregression

JEL Classification: C32, E31,F42 


\section{Introduction}

Since the global financial crisis of 2007-2008, commodity prices have surged despite slow economic recovery in major countries. As shown in Figure 1, the agricultural product, energy and metals commodity prices dropped significantly, but quickly rebounded from the global financial crisis. Such increases in commodity prices may have been caused by the abundant global liquidity, mainly resulting from unconventional monetary policies in major economies in response to the crisis. Asset purchases by the central banks in the U.S., Eurozone, J apan and the U.K. are widely believed to drive asset inflation rather than economic inflation.

Figure 1: Trends of Commodity Prices

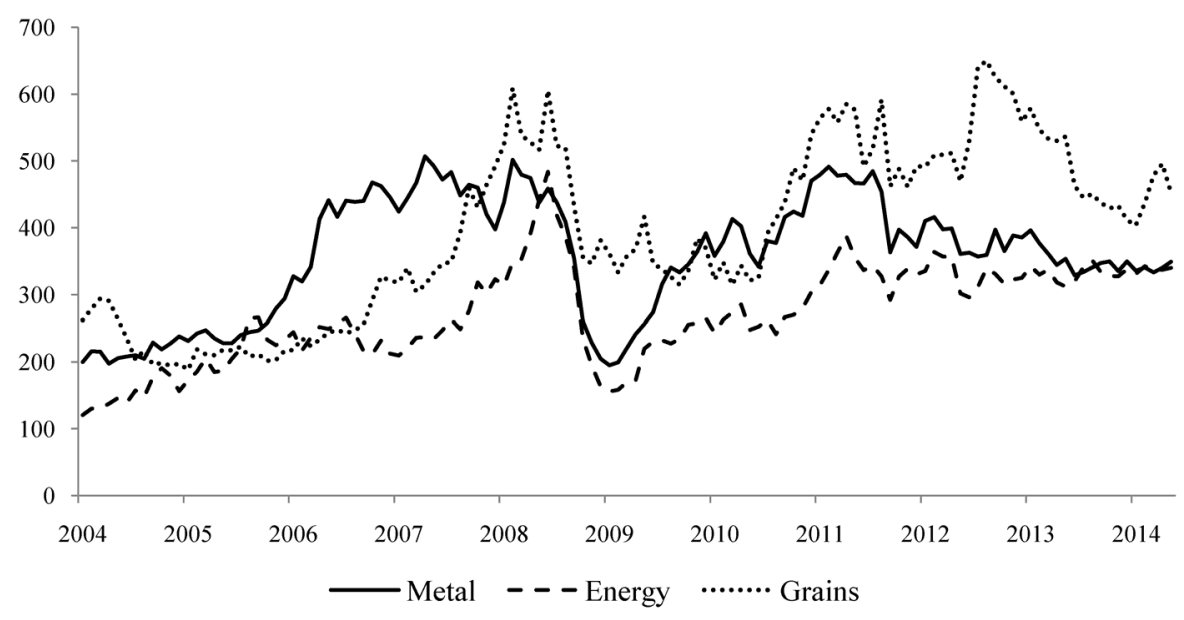

Note: The S\&P GSCl (Goldman Sachs Commodity Index) Spot Index is used.

Source: Bloomberg 
Liquidity effects can be strengthened by greater participation of financial institutions in commodity trading. For example, the U.S. Senate Permanent Committee on I nvestigations (2014, p. 13) says,

"Today, a handful of large U.S. banks and their holding companies are major players in U.S. commodities markets. ... The current level of bank involvement in critical raw materials, power generation, and the food supply appears to be unprecedented in U.S. history."

Büyüksahin and Robe (2014) also show that using the trader position data from U.S. commodity futures markets, the correlation between the rates of return on commodity prices and equity indices rises with the greater participation of hedge funds. Figure 2 shows the selected commodity futures prices and open interests which are in line with Figure 1. Cheng and Xiong (2013) refer to the process of commodity futures being a popular asset dass for portfolio investors as the 'financialization of commodity markets'.

Figure 2: Selected Commodity Futures Prices and Open Interests
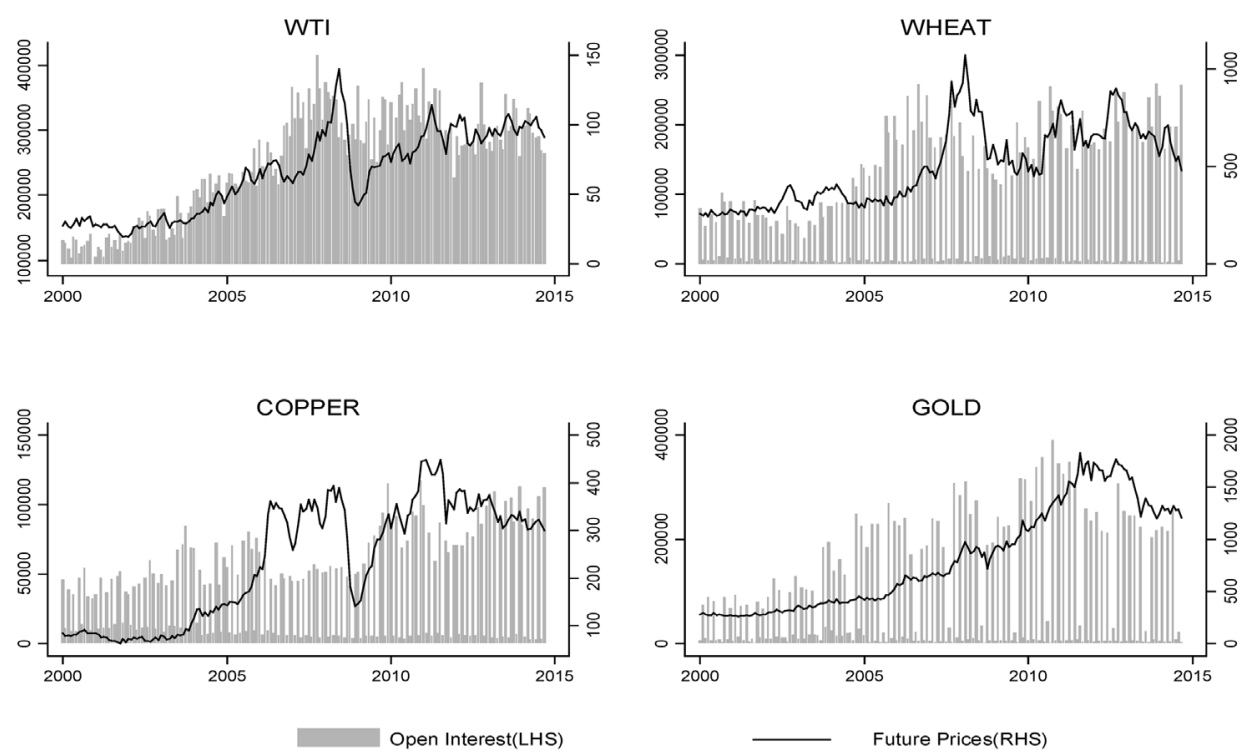
In this respect, we empirically investigate how global liquidity has affected commodity prices. Our research focuses on whether the effect of gl obal liquidity on commodity prices has become more salient since the gl obal financial crisis, in terms of their short-run relationship. For this purpose, we estimate a structural vector autoregression (SVAR) model which consists of commodity supply, demand and prices for agricultural products, metals, and energy commodities, along with global liquidity measures over the period from January 2004 to April 2014. To better capture the developments in global liquidity conditions, we employ two types of global liquidity measures: a quantity-based measure such as monetary aggregates and a price-based measure including interest rate spreads, asset prices, the risk attitude of investors, and bank lending behavior.

The key finding is that the impact of global liquidity on commodity prices has been strengthened for energy and metals commodity prices since the global financial crisis. We also find that the price-based indicator generates statistically significant results with the expected sign for the post-crisis period, while monetary aggregates fail to do so.

This paper is naturally related to the previous literature that studies the empirical relationship between global liquidity and commodity prices. However, most of the papers mainly focus on and empirically confirm a long-run relationship between them. Belke, Orth and Setzer (2010) document that commodity prices react to global liquidity much faster than goods prices do. Yu and Mallory (2014) find that the liquidity effect from the foreign currency market can diffuse across commodity markets. Using a Markov-switching vector error correction model (MS-VECM), Beckmann, Belke and Czudaj (2014) report that the effect of global liquidity on commodity prices is overall significant but has time-varying characteristics. Baffes and Savescu (2014)show that the effect of long-term interest rates on metal prices is highly significant. For a short-term relationship analysis, Noh and Lee (2012) report that prior to the recent global finandial crisis, the supply factor dominates the fluctuations of the oil price, but the demand factor and the monetary policy factor contribute more to the post-crisis oil price behavior. 
In a broad sense, there is a wide range of literature studying commodity price dynamics. It is worth mentioning the seminal research by Kilian (2009), since our econometric methodology is based on his model. He argues that although supply shocks have been regarded as the driving force of the oil price especially given the oil shock in the 1970s, precautionary demand has much greater impact than supply and aggregate demand. In addition, West and Wong (2014) fit a factor model to a panel of commodity prices to show the factor that is not contained in industrial production or exchange rates has information about the evolution of commodity prices.

The main contribution of our paper is that this research confirms the effect of global liquidity on commodity prices in a short-run manner while considering the supply and demand factors of each commodity group. In the previous literature on the long-run relationship between the two variables, demand factors are taken into consideration by using either GDP or industrial production for estimation, but supply factors are often ignored. In addition, this paper demonstrates that the price-based liquidity measure rather than the commonly-used monetary aggregates has better explanatory power for commodity price dynamics since the global financial crisis.

The rest of this paper is organized as follows. In Section II, we disauss the data and empirical methodology used in this paper. Section III shows the impacts of global liquidity on commodity prices. We condude in Section $\mathrm{IV}$. 


\section{Data and Empirical Methodology}

Considering that the research motivation of this paper lies in testing the effect of global liquidity on commodity prices, the proper choice of global liquidity measures is very important. In this section, we suggest the quantity-based measure and price-based measure. With these measures, we build up a SVAR model and provide the rationale for its structure.

\section{A. Quantity-Based Versus Price-B ased Global Liquidity Measures}

The recent literature on the measurement of global liquidity has attracted a great deal of attention from policy makers and academics alike since the conduct of unconventional monetary policies in major economies and the resulting expansion of liquidity. While monetary aggregates such as M2 are widely used in the literature, there exist a few attempts to refine the concept and measurement. On the asset side of financial institutions' balance sheet, the Committee on the Global Financial System (CGFS) considers global liquidity as the sum of domestic credit and cross-border credit (CGFS, 2011). On the liabilities side, Chen et al. (2012) suggest 'core' liquidity as residents' deposits in commercial banks and 'noncore' liquidity as cross-border deposits, loans and securities in commercial banks' liabilities. Despite their popularity and simplicity, the quantity-based measures have a crucial drawback: they tend to move very slowly in response to changes in market expectation.

Alternatively, the price-based measures incorporate the future expectations of market participants on an immediate basis. Considering the information advantage of price-based measures, and the popularity of quantity-based measures and their comparability with the previous research, this paper uses both measures and compares the results. Spedifically, the quantity-based measure in this paper is the sum of monthly M2 in the U.S., Eurozone and J apan. I ndividual monetary stocks are divided by their own consumer price index and translated into U.S. dollars by the exchange rate sat the end of each month. For the summation, the GDP in 2013 is used as a weight. These data are from the I nternational Monetary Fund (IMF) and the Bank of Korea. Figure 3 shows the quantity-based measure of global 
Figure 3: Quantity-Based Measure of Global Liquidity (Monetary Aggregates)

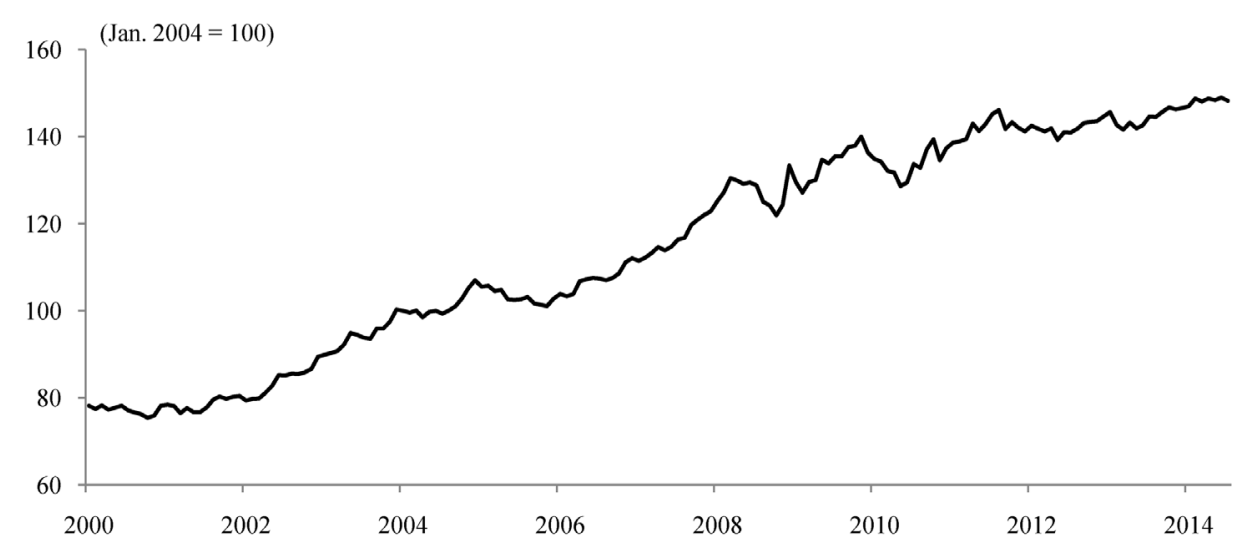

Notes: The figure shows the degree of a quantity-based global liquidity measure with a base month of January 2004. The sample period is from January 2000 to July 2014.

Sources: IMF IFS, BOK ECOS

liquidity. The quantity-based measure starts to increase and keeps rising until J une 2008. Then, it significantly dedines during the global financial crisis, and regains momentum from J une 2011 after various ups and downs.

The refined measures shown in CGFS (2011) and Chen et al. (2012) are not viable in our paper, since these indicators are based on quarterly data. Moreover, Kang and Lee (2013) show that the quantity-based measures suggested above are highly correlated in terms of the growth rates and the cydical components extracted from the statistical filters.

While the quantity-based measures are easily summable by translating different currency units to the single numeraire, typically the U.S. dollar, the price measures are very diverse and mostly non-summable. Thus, Chen et al. (2012) propose a price-based measure on the basis of dynamic factor analysis, following Matheson (2011). Using both price-based and quantity-based variables, Choi et al. (2014) divide global liquidity into three different momenta: policy-driven liquidity, market-driven liquidity, and risk averseness. We employ the methodology from Chen et al. (2012) to estimate a price-based global liquidity measure. In the spirit 
of Stock and Watson (2006), each price variable is assumed to be decomposed into a common factor and idiosyncratic factors, such that

$$
y_{t}=\lambda F_{t}+\varepsilon_{t}, \quad \varepsilon_{t} \sim N(0, \Psi)
$$

where $y_{t}$ is the vector consisting of price variables to be explained in detail later. I diosyncratic disturbances $\left(\varepsilon_{t}\right)$ are assumed to be uncorrelated across price variables. The common factor $\left(F_{t}\right)$ follows AR $(p)$ process:

$$
F_{t}=\sum_{i=1}^{p} \beta_{i} F_{t-i}+\omega_{t}, \quad \omega_{t} \sim N(0,1),
$$

where $\beta_{i}$ is are the autoregressive coefficients and $\omega_{t}$ is a normally distributed error term. The lag length, $p$, is determined using the Schwart Information Criteria (SI C). The estimated common factor can be interpreted as the weighted average of the chosen set of variables.

For model estimation, data on interest rate spreads, asset prices, investor risk attitude and bank lending behavior are from J anuary 2003 to September 2014.1) Interest rate spreads include the TED spread and Libor-OIS spread in the U.S., Eurozone, Japan and the U.K.. For asset prices, S\&P500, Euro Stoxx 50, Nikkei 225 and FTSE 100 are used as daily growth rates. I nvestor risk attitude indudes VIX, EMBI + spread and 3-month carry-to-risk ratio2) of USD/JPY and AUD/J PY. Lastly, Senior Loan Officer Surveys (SLOS)3) by the Federal Reserve, European Central Bank and the Bank of Japan are used to measure bank lending behavior. Considering that our SVAR mode is monthly, we used the monthly average of daily data. For quarterly data such as the SLOSs, we assume that there is no change in the lending behavior for each month within the same quarter. Since the

1) We used the price data beyond the sample period of commodity variables to estimate the liquidity measure with all theavailable information. The estimated result may depend on the sample period, but it turns out very robust.

2) The carry-to-risk ratio measuring the risk-adjusted return of carry trade is calculated by 3-month interest rate differentials relative to 3-month currency option volatility.

3) Higher reading means tightening credit standards for loan approval. 
scales of financial indicators in the sample are very different as noted in Table 1, standardized variables are used to estimate the model.

Figure 4 shows the estimated price-based measure. Because a higher price indictor implies a contraction in liquidity conditions, this measure can be called the price-based 'illiquidity index.' Compared to the quantity-based measure in Figure 3, this illiquidity index preemptively starts to rise in August 2007 and reaches the peak at the end of 2008. Then, it quickly drops with the first round of quantitative easing (QE) by the Federal Reserve and reaches a level similar to the pre-crisis era, until rebounding in response to the European fiscal crisis. Note that the delayed recovery of the quantity-based measure relative to the illiquidity index suggests the time lag involved in translating improved funding conditions into actual activity.

Table 1: Summary Statistics of Variables for Price-Based Measure

\begin{tabular}{lrr|r|r|c}
\multicolumn{1}{c|}{ Variable } & Mean & Std. Dev. & \multicolumn{1}{c|}{ Min. } & \multicolumn{1}{l|}{ Max. } & \multicolumn{1}{c}{$\begin{array}{c}\text { Data } \\
\text { source }\end{array}$} \\
\hline Libor-OIS spread (U.S.) & 0.2771 & 0.3685 & 0.0639 & 2.9397 & Bloomberg \\
Libor-OIS spread (Euro zone) & 0.2865 & 0.3185 & 0.0443 & 1.7040 & Bloomberg \\
Libor-OIS spread (Japan) & 0.1577 & 0.1492 & 0.0310 & 0.7322 & Bloomberg \\
Libor-OIS spread (U.K.) & 0.3185 & 0.3881 & 0.0839 & 2.2131 & Bloomberg \\
TED spread & 0.4725 & 0.4804 & 0.1180 & 3.4030 & Bloomberg \\
S\&P 500 & 0.0003 & 0.0018 & -0.0067 & 0.0050 & Datastream \\
Euro Stoxx 50 & 0.0002 & 0.0022 & -0.0062 & 0.0064 & Datastream \\
Nikkei 225 & 0.0003 & 0.0025 & -0.0100 & 0.0053 & Datastream \\
FTSE 100 & 0.0002 & 0.0017 & -0.0059 & 0.0039 & Datastream \\
EMBI+ spread & 257.52 & 132.73 & 108.41 & 698.63 & Datastream \\
VIX & 19.870 & 9.1417 & 10.787 & 62.254 & Datastream \\
Carry-to-risk ratio (AUD/JPY) & 0.4000 & 0.2037 & 0.0719 & 0.9073 & Datastream \\
Carry-to-risk ratio (USD/JPY) & 0.1798 & 0.2215 & -0.0045 & 0.7131 & Datastream \\
Bank lending survey (U.S., large \& medium firms) & 1.1723 & 24.774 & -24.1 & 83.6 & Datastream \\
Bank lending survey(U.S., small firms) & 4.0702 & 22.879 & -24.1 & 74.5 & Datastream \\
Bank lending survey(Japan, large firms) & 8.0426 & 4.2475 & -2 & 17 & Datastream \\
Bank lending survey(Japan, medium firms) & 12.766 & 6.7725 & -1 & 30 & Datastream \\
Bank lending survey(Japan, small firms) & 22.383 & 8.3518 & 5 & 41 & Datastream \\
Bank lending survey(Euro zone, large firms) & 14.872 & 21.363 & -18 & 68 & Datastream \\
Bank lending survey(Euro zone, small firms) & 11.787 & 17.968 & -14 & 63 & Datastream \\
\hline
\end{tabular}


Figure 4: Price-Based Measure of Global Liquidity (Illiquidity Index)

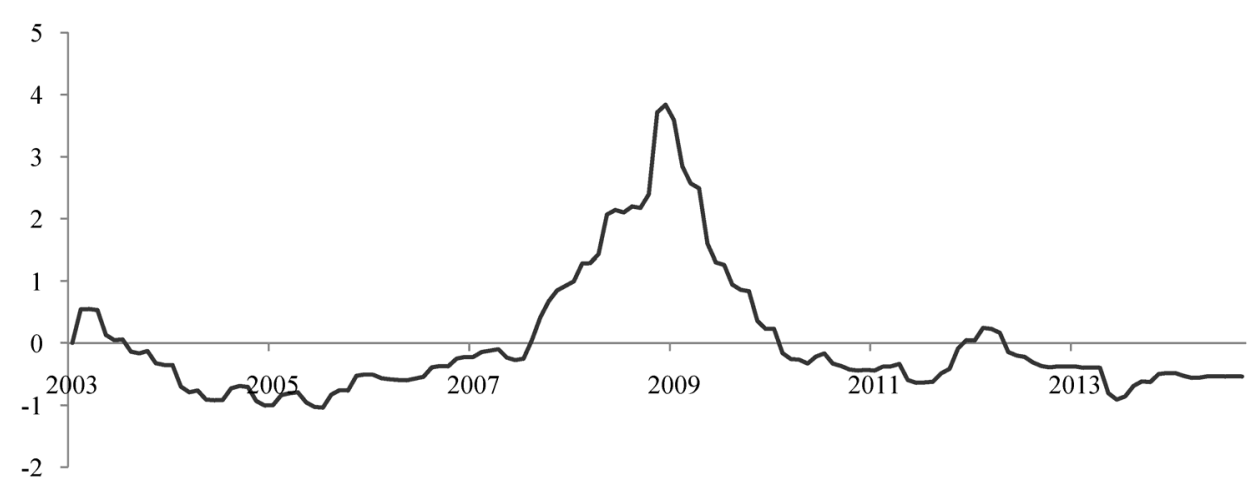

Notes: The figure shows the degree of a priced-based global liquidity measure with a base month of January 2003. The sample period is from January 2003 to September 2014.

\section{B. Commodity Prices, Supply, and Demand}

For commodity prices, S\&P GSCI (Goldman Sachs Commodity Index) Spot I ndex is used. It tradks the price of the nearby futures contracts that roll over their mature positions to the nearby positions. As a sub-index, S\&P GSCI agricultural index indudes wheat, corn, soybeans, and cotton. S\&P GSCl energy index contains arude oil, gasoline and natural gas. S\&P GSCl metals index indudes al uminum, copper, lead, nickel and zinc. We use monthly average commodity price data (agricultural products, energy, and metals), production data for the respective commodity groups, and the world industrial production index (IPI) to show an aggregate demand for commodities. 
Table 2: Data Description for Commodity Prices, Supply, and Demand

\begin{tabular}{|c|c|c|c|}
\hline Category & \multicolumn{2}{|l|}{ Description } & Source \\
\hline \multirow{3}{*}{ Price } & \multicolumn{2}{|l|}{ S\&P GSCI Industrial Metals Index Spot } & CME \\
\hline & \multicolumn{2}{|l|}{ S\&P GSCl Energy Index Spot } & CME \\
\hline & \multicolumn{2}{|l|}{ S\&P GSCI Agricultural Index Spot } & CME \\
\hline \multirow{11}{*}{ Supply } & Energy Intelligence Group Crude Oil Production & Data & NYMEX \\
\hline & Aluminum Primary Production World Total & & WBMS \\
\hline & Refined Copper Production World Total & & WBMS \\
\hline & Zinc Slab Production World Total & & WBMS \\
\hline & Refined Lead Production World Total & & WBMS \\
\hline & IISI Total Global Iron Production Data & & $\| S \mid$ \\
\hline & Smelter/ Refined Nickel Production World Total & & WBMS \\
\hline & Global Corn Production & & F.O. Licht \\
\hline & Global Milled Rice Production & & USDA \\
\hline & Global Wheat Production & & F.O. Licht \\
\hline & Coal Production - Total World, British Petroleum & Statistical & DOE \\
\hline Demand & World Industrial Production Index & & Bloomberg \\
\hline
\end{tabular}

We construct a production index for each commodity group using the production data of the individual commodities belonging to that group with the GSCl index weight, which is presented in Table 3. Note that the production data of some commodities induded in $\mathrm{GSCl}$ are not available. In such a case, the weight was recalculated based on the available set of commodities within its group. Table 4 provides the summary statistics of commodities price index, the constructed production index and IPI with global liquidity measures in Section II .

Table 3: S\&P GSCI Index Reference Percentage Dollar Weights')

\begin{tabular}{|c|c|c|c|c|c|}
\hline Energy & $100.00 \%$ & Metals & $100.00 \%$ & Agricultural products & $100.00 \%$ \\
\hline Crude Oil & $70.50 \%$ & Aluminum & $31.08 \%$ & Wheat & $25.08 \%$ \\
\hline Gasoline $^{2)}$ & $7.02 \%$ & Copper & $45.95 \%$ & Corn & $27.64 \%$ \\
\hline Heating $\mathrm{Oil}^{2)}$ & $7.03 \%$ & Lead & $5.77 \%$ & Soybeans ${ }^{2)}$ & $15.19 \%$ \\
\hline Gas $\mathrm{Oil}^{2)}$ & $11.09 \%$ & Nickel & $9.71 \%$ & Cotton $^{2)}$ & $10.66 \%$ \\
\hline \multirow[t]{3}{*}{ Natural Gas $^{2)}$} & $4.35 \%$ & Zinc & $7.49 \%$ & Sugarr $^{2)}$ & $13.58 \%$ \\
\hline & & & & Coffee $^{2)}$ & $6.08 \%$ \\
\hline & & & & $\mathrm{Cocoa}^{2)}$ & $1.79 \%$ \\
\hline
\end{tabular}

Notes: 1) The weights are determined by using the previous yearís average contract reference price (ACRP) for each individual commodity, and the weights for the 2012 S\&P GSCl were used.

2) The supply data are not available. 


\section{BOK Working Paper No.2015-14(2015.5)}

Table 4: Summary Statistics of Key Variables

\begin{tabular}{|c|c|c|c|c|c|c|c|c|c|}
\hline & \multicolumn{3}{|c|}{ Production } & \multicolumn{3}{|c|}{ Price } & \multirow{2}{*}{$\mid \mathrm{PI}$} & \multirow{2}{*}{$\frac{\text { Global }}{\text { Money }}$} & \multirow{2}{*}{$\frac{\text { Liquidity }}{\text { Illiquidity }}$} \\
\hline & Metals & Energy & Agri. & Metals & Energy & Agri. & & & \\
\hline Mean & 1.27 & 0.75 & 4.45 & 4.57 & 3.46 & 4.99 & 102.05 & 15.11 & 0.02 \\
\hline Median & 1.27 & 0.74 & 2.94 & 4.62 & 3.38 & 4.93 & 103.20 & 15.57 & -0.37 \\
\hline Maximum & 1.58 & 0.81 & 21.31 & 6.45 & 6.15 & 8.26 & 109.30 & 17.86 & 3.84 \\
\hline Minimum & 0.98 & 0.70 & 0.44 & 2.48 & 1.65 & 2.39 & 90.40 & 11.82 & -1.04 \\
\hline Std. Dev & 0.15 & 0.03 & 4.89 & 1.13 & 0.91 & 1.65 & 4.49 & 1.98 & 1.06 \\
\hline Skewness & 0.06 & 0.50 & 1.71 & -0.33 & 0.04 & 0.06 & -0.71 & -0.34 & 1.85 \\
\hline Kurtosis & -0.97 & -0.73 & 2.11 & -1.00 & -0.39 & -1.16 & 0.06 & -1.44 & 2.96 \\
\hline Obs & 124 & 124 & 124 & 124 & 124 & 124 & 124 & 124 & 124 \\
\hline
\end{tabular}

\section{Estimating Structural VAR Models}

In Table 5 we present the result from unit-root tests of each set of data; we use the Augmented Dickey Fuller test for stationarity. The first panel of the table shows the test result for the level data and the second panel shows the result for the first-differenced data. As Table 5 reports, all data series have a unit root, but the first-differenced series are stationary.

In principle, while running a regression with differenced data has been a common treatment for non-stationary time series, information on the level data may be lost by differencing. One of the most important items of information is a long-run relationship among variables. Hence, a vector error correction model (VECM) can be an alternative econometric approach to keep the level of information and long-run relationship but relieve the issue of non-stationary. 
Table 5: Augmented Dickey Fuller Unit Root Test

\begin{tabular}{l|c|cc|c|c}
\hline & Model & Lags & $5 \%$ & Statistics & Result \\
Agricultural Production & CT & 14 & -3.41 & -3.03 & Non-stationary \\
Energy Production & CT & 1 & -3.41 & -2.67 & Non-stationary \\
Metals Production & CT & 12 & -3.41 & -2.57 & Non-stationary \\
Agricultural Price & NCNT & 0 & -1.94 & 0.21 & Non-stationary \\
Energy Price & CT & 1 & -3.41 & -3.39 & Non-stationary \\
Metals Price & CNT & 1 & -2.86 & -2.26 & Non-stationary \\
Monetary Aggregates & CT & 0 & -3.41 & -2.35 & Non-stationary \\
Illiquidity Index & NCNT & 1 & -1.94 & -1.72 & Non-stationary \\
Industrial Production Index & CNT & 8 & -2.86 & -2.03 & Non-stationary \\
\hline DAgricultural Production & NCNT & 13 & -1.94 & -3.92 & Stationary \\
DEnergy Production & NCNT & 0 & -1.94 & -10.91 & Stationary \\
DMetals Production & CNT & 11 & -2.86 & -2.89 & Stationary \\
DAgricultural Price & NCNT & 0 & -1.94 & -11.76 & Stationary \\
DEnergy Price & NCNT & 0 & -1.94 & -8.49 & Stationary \\
DMetals Price & NCNT & 0 & -1.94 & -9.41 & Stationary \\
DMonetary Aggregates & CNT & 0 & -2.86 & -11.78 & Stationary \\
Dilliquidity Index & NCNT & 0 & -1.94 & -7.94 & Stationary \\
DIndustrial Production Index & NCNT & 0 & -1.94 & -3.76 & Stationary \\
\hline
\end{tabular}

Note: CT (with constant and trend), CNT (with constant, but no trend), NCNT (no constant and trend)

In this paper, however, we focus on short-run portfolio adjustment and its effect on the commodity prices. Our data starts from J anuary 2004 to April 2014, which reflects about 10 years. Most of the previous papers that studied the effect of monetary aggregates on commodity prices are based on long-term data horizons. In contrast, our paper focuses primarily on the effects of price-based global liquidity on commodity prices in terms of their short-term relationship. Also, a VECM is more likely to cause a Typel error because of its weak power. Therefore, we use a VAR instead of a VECM.

More specifically, we estimate a structural VAR model by using the first differences of the variables. In equation (3), $\Delta p_{t}$ refers to the vector of all differenced variables. Contemporaneous effects of the SVAR model are defined from imposing restrictions on the $4 \times 4$ matrix, $B$. This restriction by the choice of order describes a sequential causality within the matrix (Amisano and Giannini, 1997; Lütkepohl, 2007). Because we consider the two kinds of global liquidity measures introduced in Section $\mathbb{I}$, the two sets of the SVAR model are presented as follows. 


$$
\begin{gathered}
B \Delta p_{t}=\Gamma_{0}+\Gamma_{1} \Delta p_{t-1}+\Gamma_{2} \Delta p_{t-2}+\cdots+\Gamma_{J} \Delta p_{t-J}+\varepsilon_{t}, \\
\Delta p_{t}=\left[\begin{array}{c}
\triangle \text { Money } \\
\triangle \text { Supply } \\
\triangle \text { Demand } \\
\triangle \text { Price }
\end{array}\right] \text { or } \quad \Delta p_{t}=\left[\begin{array}{c}
\triangle \text { Iliquidity } \\
\triangle \text { Supply } \\
\triangle \text { Demand } \\
\triangle \text { Price }
\end{array}\right]
\end{gathered}
$$

The terms, Money and Iliquidity, are the monetary aggregate and the illiquidity index, respectively. Supply represents the constructed composite production index for each commodity group, and Demand denotes the aggregate demand for commodities.

In equation (4), $\Gamma_{0}$ is a $4 \times 1$ vector of constant terms of each variable, and all other $\Gamma_{i}$ are $4 \times 4$ matrices of parameters. We postulate that $B^{-1}$ has a recursive structure such that the reduced form error term $u_{t}$ can be decomposed according to $u_{t}=B^{-1} \varepsilon_{t}$.

$$
\begin{aligned}
& \triangle p_{t}=B^{-1} \Gamma_{0}+B^{-1} \Gamma_{1} \Delta p_{t-1}+B^{-1} \Gamma_{2} \Delta p_{t-2}+\cdots+B^{-1} \Gamma_{J} \Delta p_{J}+B^{-1} \varepsilon_{t},
\end{aligned}
$$

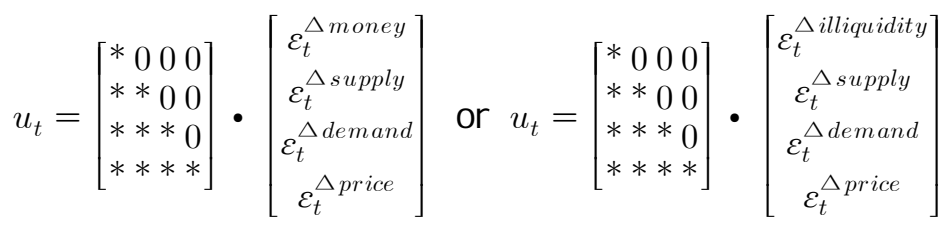

The monetary aggregate and illiquidity index appear in the first row of two cases because we assume they are exogenous policy instruments compared to the other variables of the model. This setup follows Belke, Bordon and Volz (2013), who assume that policy instruments are independently determined by the government and are not immediately affected by other markets within a month. Since supply factors such as finding a new mine, drought/floods, typhoons affect the amount of harvested commodities, this can be the next independent variable. The demand factor can be possibly affected by the policy or supply factor, but the demand factor cannot affect the supply or policy instantaneously within a month. 
Then we place the commodity price index at the end row of the matrix since commodity markets are susceptible to contemporaneous shocks of each of the other variables.

The number of lags, $J$, is determined on the basis of the Schwart I nformation Criterion (SIC). Since this paper aims to examine the short-term effect of monetary policy shocks within a couple of years and identify portfolio adjustment behavior from investors, we limit our trial to a maximum of 30 lags. However, if the suggested number of lags exceeds 20 , we overview the error term of prices and choose a lag that is dose to a normal distribution with least autocorrelation and heteroskedasticity. Table 6 provides the results for each case.

After estimating the reduced form VAR model, we apply a sequential elimination process4) for the parameters based on the top-down procedure with the Akaike Information Criteria (AIC) (Lütkepohl, 2007). By the definition of sequential elimination, this method consecutively deletes parameters that result in the biggest improvement of the AIC. Once no additional parameter reduction is possible without worsening the information criteria measure, this process stops eliminating regressors. With non-zero parameters that have gone through the sequential elimination process, we estimate the structural VAR model. This process can be effective in that restricting the VAR model with a sequential elimination process has led to a more reliable effect to the shocks; hence, this illustrates a neat impulse response.

Table 6: Lag Length Selection Based on SIC

\begin{tabular}{c|c|c|c|c} 
& \multicolumn{2}{|c|}{ Test for monetary aggregates } & \multicolumn{2}{c}{ Test for illiquidity index } \\
\cline { 2 - 5 } & Whole period & Post-crisis period & Whole period & Post-crisis period \\
$\begin{array}{c}\text { Agricultural } \\
\text { products }\end{array}$ & 15 & 8 & 15 & 8 \\
Energy & 15 & 8 & 15 & 8 \\
Metals & 10 & 6 & 10 & 6 \\
\hline
\end{tabular}

4) In this paper we performed the model estimation with computing impulse responses by using the JMulTi software package. 


\section{I mpacts of Global Liquidity on Commodity Prices}

In this section, we illustrate the impulse response functions of the estimated SVAR model from the shocks of the monetary aggregates and illiquidity index for each commodity group.5) Given the responses to a one standard deviation shock, each confidence interval is calculated at a 95\% level. We use bootstrapping (500 iterations), since Hall (1992) said only a small number of resamplings can result in robust properties of confidence intervals.

In estimation, the two different results based on a monetary shock and an illiquidity shock are provided. The monetary shock is a one standard deviation of the monetary aggregate defined in Section $\mathbb{I}$, and the illiquidity shock is also a one standard deviation of the price-based measure estimated by the dynamic factor model of equations (1) and (2) in the same section. Moreover, we also compare the two periods; the whole period ( an. $2004 \sim$ Apr. 2014) and the period after the global financial crisis ( an. $2008 \sim$ Apr. 2014). The timing of the global financial crisis may be arbitrary, but it is chosen given the fact that the Federal Reserve introduced its Term Auction Facility (TAF) on December 12, 2007, which injects rescue funds into all depository institutes.

Figure 5 describes the cumulative responses of the agricultural commodity price index to the shock from the monetary aggregate, supply, and demand factor in panel (a) and to the shock from the illiquidity index, supply, and demand factor in panel (b), respectively. A shock from the monetary aggregate leads to an increase in the agricultural commodity price index. On the contrary, a one standard positive deviation in the illiquidity index results in an unexpected price increase. For the agricultural market specific fundamentals, the supply factor is statistically insignificant in the both cases, but higher industrial demand increases the price of agricultural product in panel (a).

Figure 6 describes the period after the global financial crisis to highlight the impact of global liquidity in comparison with Figure 5. On impact, the monetary

5) The test for autoregressiveconditional heteroscedasticity (ARCH) and non-normality in all data seriesis rejected. Thus, it should be considered that these effects can affect the confidence interval (Lütkepohl, 2005). 
aggregate shock increases agricultural prices, but this effect quickly vanishes. However, the illiquidity shock reduces agricultural prices although it is barely significant in 95\% interval, as shown in panel (b). In panels (a) and (b), the demand factor shows statistically significant results with expected sign.

Figures 7 and 8 illustrate the effect on the energy commodity price index during the whole sample period and the post-crisis period, respectively. In Figure 7, both monetary aggregates and illiquidity index shocks do not produce significant change in the energy commodity price index with decisive direction. In Figure 8, however, while the monetary aggregate shock does not produce any significant changes in the energy commodity price, the illiquidity index shock delivers statistically a significant price dedine. In both figures, a supply shock does not generate a statistically significant effect on the price. However, a demand shock produces a significant positive price response, except for panel (b) in Figure 7.

The effects on the metals commodity price index are presented in Figures 9 and 10 for the two periods. While the illiquidity shock leads to a price decrease in the both period, the elasticity of price to the illiquidity shock has noticeably increased for the post-crisis period. In contrast, the monetary aggregate shock either decreases metals commodity prices in an unexpected direction during the whole sample period or fails to generate significant results for the post-crisis period. 
Figure 5: Responses of Agricultural Commodity Price Index (Jan. 2004 Apr. 2014)

(a) Shocks to Monetary Aggregates, Supply and Demand
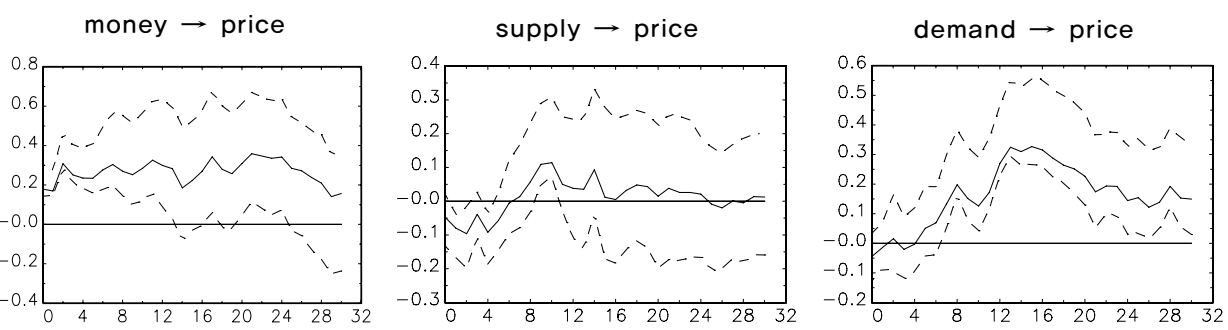

(b) Shocks to Illiquidity Index, Supply and Demand
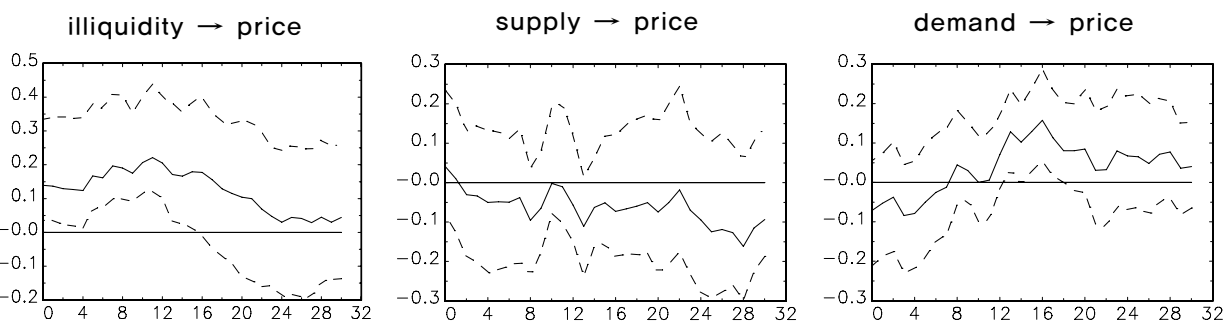

Figure 6: Responses of Agricultural Commodity Price Index

(Jan. $2008 \sim$ Apr. 2014)

(a) Shocks to Monetary Aggregates, Supply and Demand
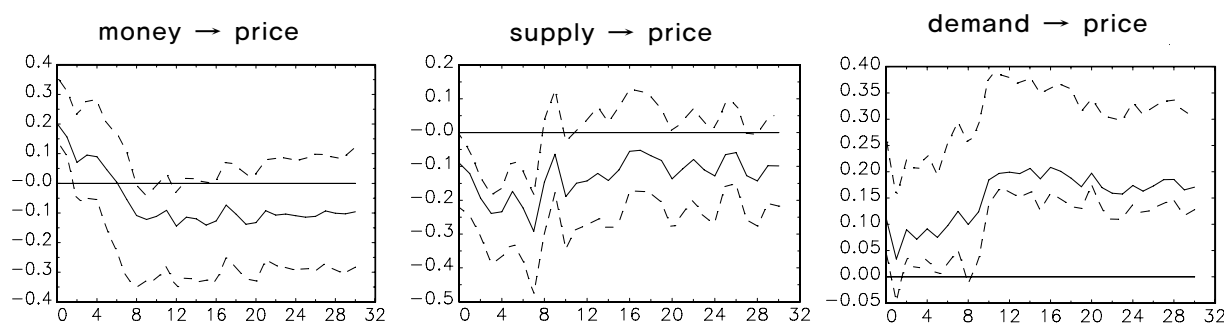

(b) Shocks to Illiquidity Index, Supply and Demand
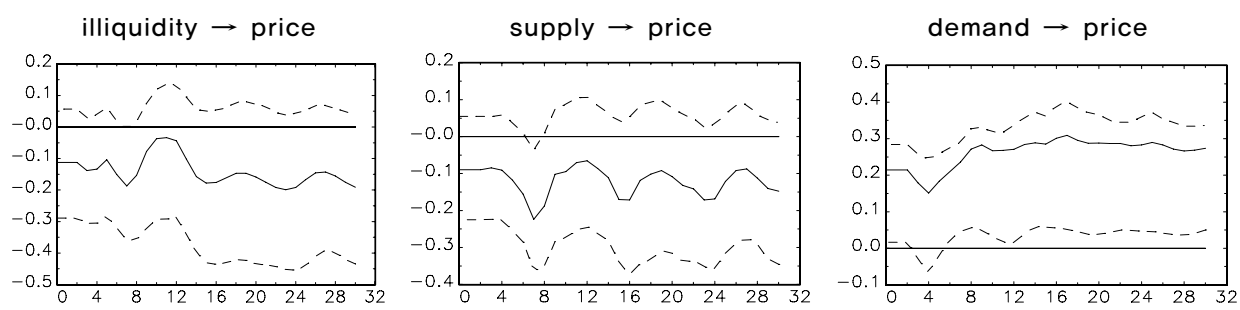
Figure 7: Responses of Energy Commodity Price Index (Jan. 2004 Apr. 2014)

(a) Shocks to Monetary Aggregates, Supply and Demand
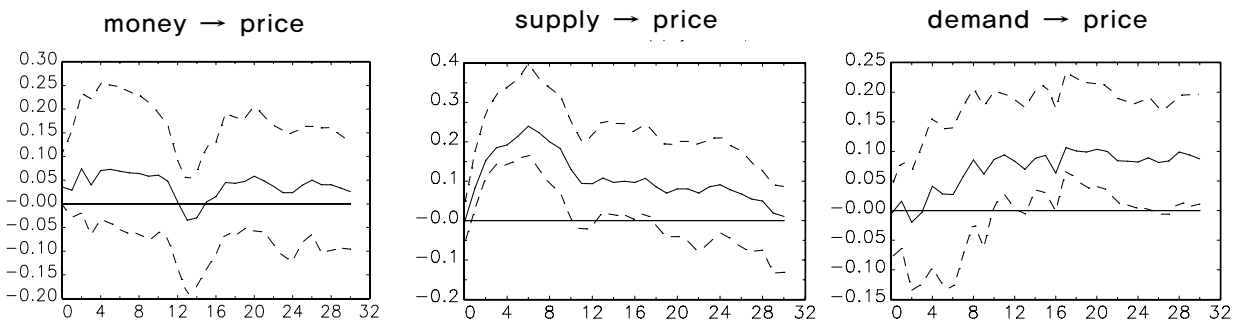

(b) Shocks to Illiquidity Index, Supply and Demand
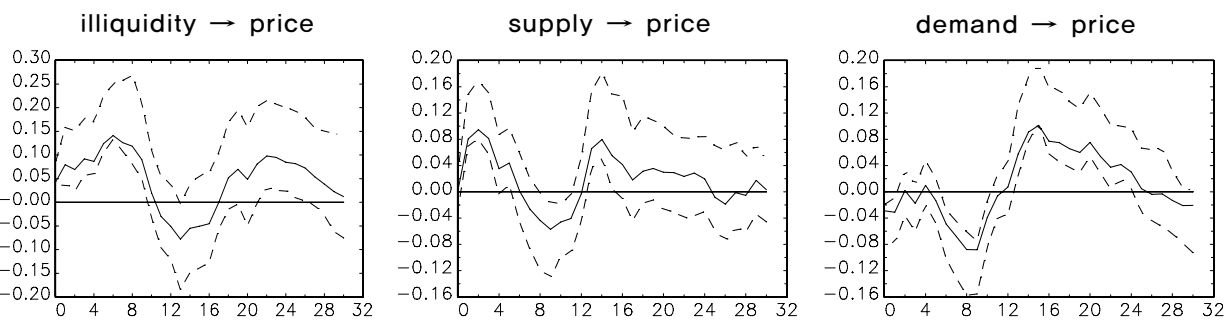

Figure 8: Responses of Energy Commodity Price Index

(Jan. 2008 Apr. 2014)

(a) Shocks to Monetary Aggregates, Supply and Demand
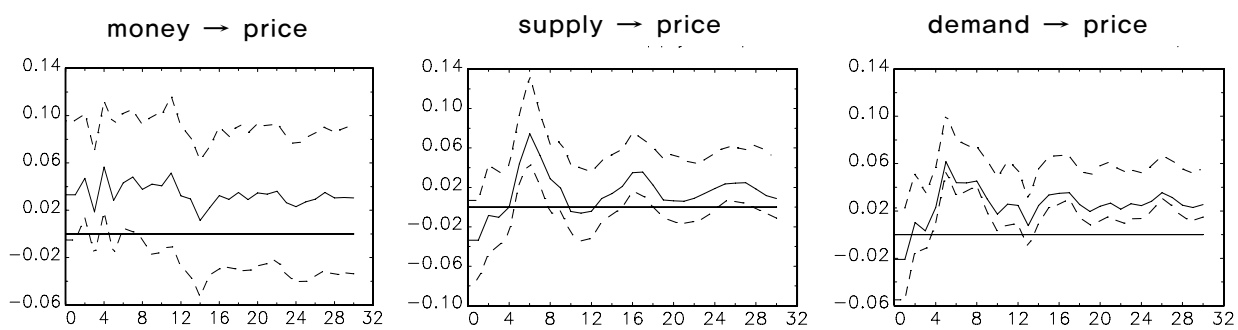

(b) Shocks to Illiquidity Index, Supply and Demand
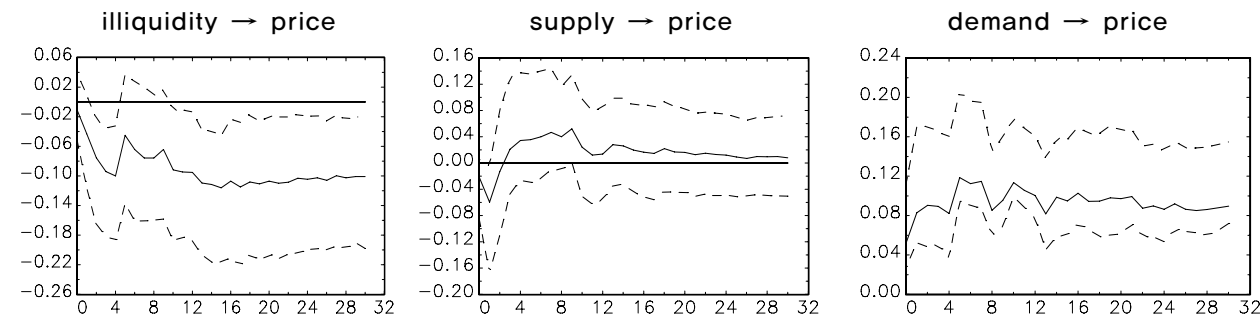
Figure 9: Responses of Metals Commodity Price Index (Jan. 2004 Apr. 2014)

(a) Shocks to Monetary Aggregates, Supply and Demand
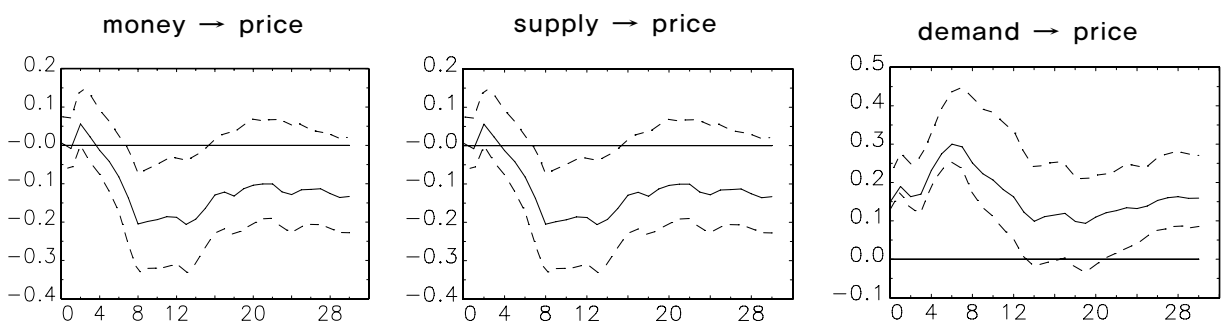

(b) Shocks to Illiquidity Index, Supply and Demand
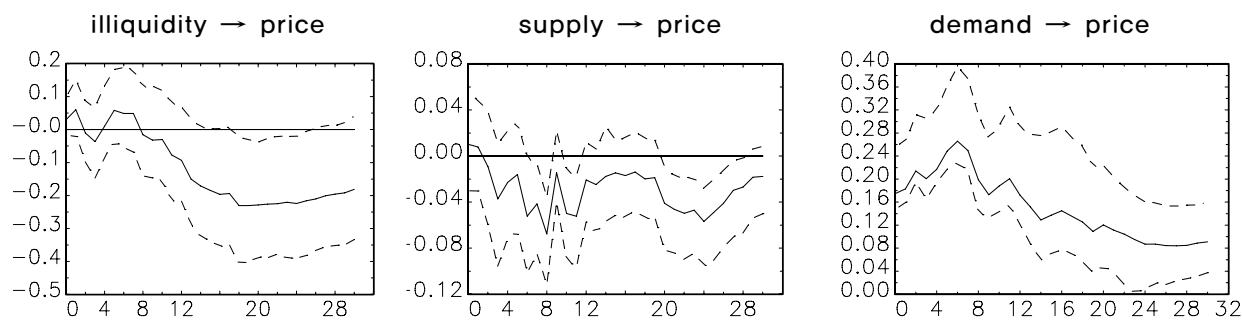

Figure 10. Responses of Metals Commodity Price Index

(Jan. 2008 Apr. 2014)

(a) Shocks to Monetary Aggregates, Supply and Demand
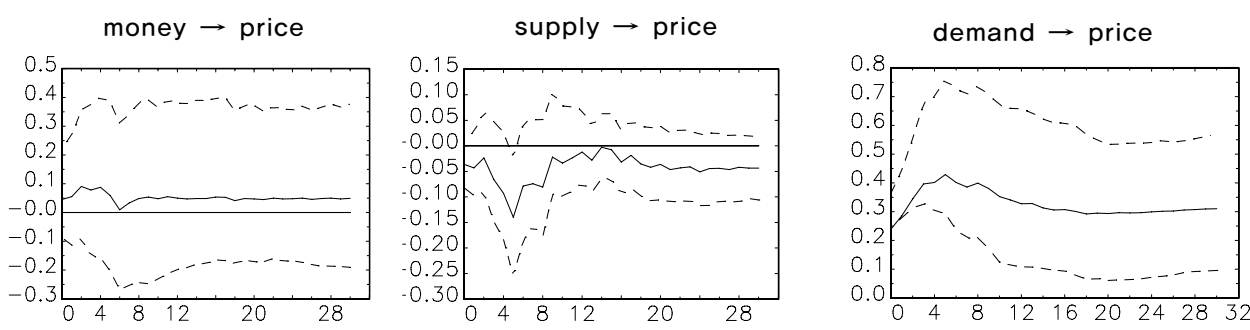

(b) Shocks to Illiquidity Index, Supply and Demand
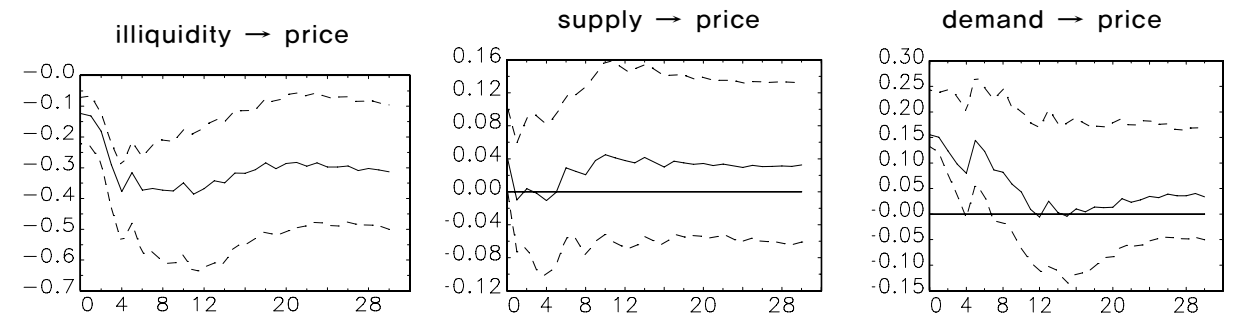
For panels (a) and (b) in Figure 9, both supply and demand shocks deliver a statistically significant impact on metals commodity prices for the whole sample period with expected sign. However, for panel (b) in Figure 10, their effects on metals commodity prices are lessened, which might mean that the impact of market fundamentals on metals commodity prices dedines after the crisis while the role of illiquidity shocks is strengthened.

\section{Conclusion}

Monetary easing by central banks in major economies and greater participation of financial institutions in commodity trading may enhance the financialization of commodity markets. This paper empirically investigates the idiosyncratic impact of global liquidity on three commodity groups: agricultural products, industrial metals and energy products. We construct an SVAR model to address this question for each commodity group. To capture the global liquidity condition that is a key task in this research, the price-based liquidity measure as well as widely-used monetary aggregates is employed. In addition, unlike the previous literature focusing on the long-term relationship between global liquidity and commodity prices, this paper incorporates the supply factor of each commodity and verifies investors' portfolio adjustment behavior from the global liquidity effect.

Our key finding in this paper is that the effect of global liquidity has been more pronounced for energy and metals commodity prices since the global financial crisis. This might imply that monetary policy normalization or stricter regulation on investment bank trading may influence commodity prices via liquidity contraction.

We also find that a price-based liquidity measure may be more useful for explaining commodity price dynamics in the post-crisis period than commonly-used monetary aggregates, at least in the energy and metals sectors. This result implies that the financial price variables quickly reflect information about market participants, which is highlighted in the post-crisis period. On the other hand, it can be interpreted that the traders having positions in commodity futures markets are more sensitive to the movements of various price-based measures compared to 


\section{$21 \quad$ BOK Working Paper No.2015-14(2015.5)}

the slow-moving quantity-based ones such as monetary aggregates. For instance, if the central banks in major economies start tapering their quantitative easing policies, commodity prices could be affected by liquidity contractions through price-based illiquidity channels even before actual monetary aggregates decrease. 


\section{References}

Amisano G., and C. Giannini (1997), “Topics in Structural VAR Econometrics,” Second Edition, Springer, Berlin.

Baffes, J., and C. Savescu (2014), "Monetary Conditions and Metal Prices," Applied Economics Letters, Vol. 21(7), pp. 447-452.

Beckmann, J., A. Belke, and R. Czudaj (2014), "Does Global Liquidity Drive Commodity Prices," Forthcoming at Journal of Banking and Finance.

Belke, A., I. G. Bordon, and U. Volz (2013), "Effects of Global Liquidity on Commodity and Food Prices," World Development, Vol. 44, pp. 31-43.

Belke, A., W. Orth, and R. Setzer (2010), "Liquidity and the Dynamic Pattern of Asset Price Adjustment: A Global View," Journal of Banking and Finance, Vol. 34, pp.1933-1945.

Büyüksahin, B., and M. A. Robe (2014), "Sepculators, Commodities and Cross-Market Linkages," Journal of International Money and Finance, Vol. 42, pp.38-70.

Chen, S., P. Liu, A. Maechler, C. Marsh, S. Saksonovs, and H. S. Shin (2012), "Exploring the Dynamics of Global Liquidity," IMF Working Paper WP/12/246.

Cheng, I., and W. Xiong (2013), "The Financialization of Commodity Markets," NBER Working Paper 19642.

Choi, W., T. Kang, G. Kim, and B. Lee (2014), "Global Liquidity Transmission to Emerging Market Economies, and Their Policy Responses," BOK Working Paper, No. 2014-38.

Committee on the Global Financial System(CGFS) (2011), "Global Liquidity Concept, Measurement and Policy Implications,” CGFS Papers Vol. 45.

Hall, P. (1992), "On Bootstrap Confidence Intervals in Nonparametric Regression," The Annals of Statistics, Vol. 20(2), pp. 695-711.

International Monetary Fund (2013), "Global Liquidity - Credit and Funding Indicators," IMF Policy Paper, July 16, 2013. 


\section{$23 \quad$ BOK Working Paper No.2015-14(2015.5)}

Lütkepohl, H. (2007), "New Introduction to Multiple Time Series Analysis," Springer, Berlin.

Kang, H., and S. Lee (2013), "Global Liquidity and Cross-Border Capital Flows," (in Korean) KCMI Research Paper 13-02.

Kilian, L. (2009), "Not All Oil Price Shocks Are Alike: Disentangling Demand and Supply Shocks in the Crude Oil Market," American Economic Review, Vol. 99(3), pp. 1053-1069.

Matheson, T. (2011), "Financial Conditions Indexes for the United States and Euro Area," IMF Working Paper WP/11/93.

Noh, J., and K. Lee (2012), "The Impact of Monetary Easing in Major Countries on the International Oil Price,"(in Korean) Bank of Korea Overseas Economy Focus, Vol. 20, pp. 1-10.

Stock, J., and M. Watson (2006), "Forecasting with Many Predictors," In Handbook of Economic Forecasting, Volume 1, edited by Elliot, G., Granger, C.W.J. and Timmermann, A., 515-554, North-Holland.

Yu, J., and M. Mallory (2014), "Exchange Rate Effect on Carbon Credit Price via Energy Markets," Journal of International Money and Finance, Vol. 47, pp. 145-161.

U.S. Senate Permanent Committee on Investigations (2014), Wall Street Bank Involvement with Physical Commodities 11-18-14.

West, K., and K. Wong(2014), "A Factor Model for Co-movement of Commodity Prices," Journal of International Money and Finance, Vol. 42, pp. 289-309. 


\section{<Abstract in Korean>}

\section{강 현 주*, 유 복 근 ${ }^{* *}$ 유 종 민 ${ }^{* * *}$}

본 연구는 최근의 글로벌 금융위기 이후 주요국에서의 양적완화(monetary easing) 실시에 따른 글로벌 유동성 증가와 금융기관들의 상품시장(commodity market)에 대한 투자확대가 동 시장의 금융화(financialization)를 촉진시켜왔음에 주목하였다. 이에 따라 본 논문에서는 상품시장을 농산물, 에너지, 금속부문으로 각각 구분한 후, 상품군별 가격 및 공급, 글로벌 수요 및 유동성으로 구성된 구조 벡터자기회귀(Structural Vector Autoregressive) 모형을 이용하여 글로벌 유동성이 상품가격에 미친 영향을 분석하였다.

분석 결과, 먼저 글로벌 유동성이 상품가격에 미치는 영향이 에너지와 금속 상품가격 중심으로 대체로 글로벌 금융위기 이후에 보다 뚜렷하게 나타났다. 특히 글로벌 금융위기 이후 기간의 경우, 가격에 기반한 유동성 지표(price-based liquidity measure)가 흔히 사용되는 양적 유동성 지표(monetary aggregates)에 비해 상품가격의 변동을 보다 잘 설명하는 것으로 나타났다.

핵심 주제어: 상품가격, 글로벌 유동성, 구조 벡터자기회귀 모형

\section{JEL Classification: C32, E31,F42}

\footnotetext{
* 자본시장연구원 연구위원

** 한국은행 경제연구원 미시제도연구실장

*** 홍익대학교 조교수
}

이 연구내용은 집필자의 개인의견이며 한국은행의 공식견해와는 무관합니다. 따라서 본 논문의 내용을 보도하거나 인용할 경우에는 집필자명을 반드시 명시하여 주시기 바랍니다. 